\title{
A sexually transmitted disease: History of AIDS through philately
}

\author{
Cinsel yolla geçen bir hastallk: AIDS'in filatelik tarihi
}

\author{
Emine Elif Vatanoğlu' ${ }^{1}$, Ahmet Doğan Ataman² \\ 'Department of Medical History and Ethics, Faculty of Medicine, Yeditepe University, Istanbul, Turkey \\ ${ }^{2}$ Medical University of Vienna, Vienna, Austria
}

\section{Abstract}

AIDS has become the new plague; a disease that is not only physically and psychologically debilitating, but culturally and socially devastating as well. Like the plague, AIDS has caused fear, prejudice and even panic in society. Although there are remarkable improvements in the diagnosis and treatment of the disease, AIDS continues its grim passage around the globe. After a slight downturn in the early 1990's, it then returned with a vengeance. By the end of the $20^{\text {th }}$ century, AIDS was reliably estimated to have caused over 20 million deaths throughout the world. At the same time, 40 million people were estimated to be HIV positive. This paper provides an overview of the history of AIDS, including the discovery and its progress in the world through philately. Philately is the study of stamps and postal history and other related items. Philately involves more than just stamp collecting, it contains the study of the design and educational impact of a philatelic material. We have presented AIDS stamps produced world-wide to emphasize the history of AIDS. (J Turkish-German Gynecol Assoc 2011; 12: 192-6)

Key words: AIDS, HIV, infection, immunity, history, philately

Received: 28 July, 2011

Accepted: 29 July, 2011

\section{Introduction}

By the 1960's informed medical opinion was firmly convinced that the age of pandemics and plagues was over. Indeed, in 1969 no less a figure than the US Surgeon General solemnly announced that "the book of infectious disease is now closed." However, towards the end of the twentieth century, the world suddenly found itself faced with what appeared to be potentially the worst pandemic in human history-namely, AIDS (acquired immunity deficiency syndrome). This is caused by a virus known as HIV (human immunodeficiency virus) which, over a period, attacks a variety of white blood cells essential to the body's immune system. When this system finally breaks down, the body is powerless to defend itself against attack by opportunistic diseases, including cancer, until it is overwhelmed and the victim dies (1). This disease attracted so much attention all over the world that many philatelic materials have been published from different countries to draw public attention to the importance and severity of the disease. The collection and study of philatelic materials
Özet

Geçtiğimiz yüzyıl ortaya çıkan yeni hastalıklardan birisi AIDS'tir. Kısa sürede çağımızın en tehlikeli hastalığı haline gelen AIDS, ilk kez 1981'de ABD'de kaposi sarkoma (kemik, kıkırdak, deri ve lifli dokularda tutunan bir kanser türü) adlı bir hastalığın olağandışı artışı sonucunda tespit edildi. "Edinilmiş bağışıklık yetersizliği sendromu" sözcüklerinin İngilizce baş harflerinden oluşan AIDS, birkaç yll içinde dünyanın dört bir köşesine yayılarak ölümcül bir salgın boyutuna ulaştı. BM'nin geçen yıl yayınladığı rapora göre, dünyada 40 milyona yakın insan AIDS'in pençesinde boğuşuyor. Bu yeni hastalığın farkına varılmasından dört yıl sonra, hastalığa sebep olan ve cinsel ilişkiyle, kan yoluyla ve anneden bebeğe geçerek insandan insana bulaşan HIV virüsü tanımlandı. Bu yazıda, tematik filateli yoluyla HIV virüsünün keşfinin öyküsü anlatılamaktadır. (J Turkish-German Gynecol Assoc 2011; 12: 192-6)

Anahtar kelimeler: AIDS, HIV, enfeksiyon, bağışıklık, tarih, filateli

Geliş Tarihi: 28 Temmuz 2011

Kabul Tarihi: 19 Temmuz 2011

like stamps, FDC's, entries and cancellations related to medicine is termed medical philately and the concept of AIDS has been presented frquently in medical philately (Figure 1).

The historical origins of AIDS remain something of a mystery. It appears likely that chimpanzees in the jungles of the Congo basin had long been carriers of a virus genetically similar to HIV, but remained unaffected by it. Sometime around 1970, this virus evolved into HIV, which was transferred to humans who hunted and ate these chimpanzees (Retrospective examination of Central African blood samples reveal no evidence of HIV before 1971). From there it spread, at first largely unnoticed (1). However, there is some curious evidence that appears to contradict this hypothesis. Retrospective tests indicate that a British seaman died of AIDS in Manchester as early as 1959. Another case has been traced to a young adolescent from Missouri who died in 1968. Also, there were outbreaks of diseases now known to be AIDS-related in Central Africa during the 1950's. All this indicates that HIV may initially have crossed into humans much earlier than 1970, and then either died out or lain dormant (Figure 2).

Address for Correspondence: Yard. Doç. Dr. Emine Elif Vatanoğlu, Kayışdağ Cad. 66 Ağustos Yerleşimi 34755 Kadiköy, İstanbul, Turkey

Phone: +9021657800 00-3087 e.mail: drvatanoglu@yahoo.com

(C) Copyright 2011 by the Turkish-German Gynecological Education and Research Foundation - Available on-line at www.jtgga.org doi:10.5152/jtgga.2011.45 


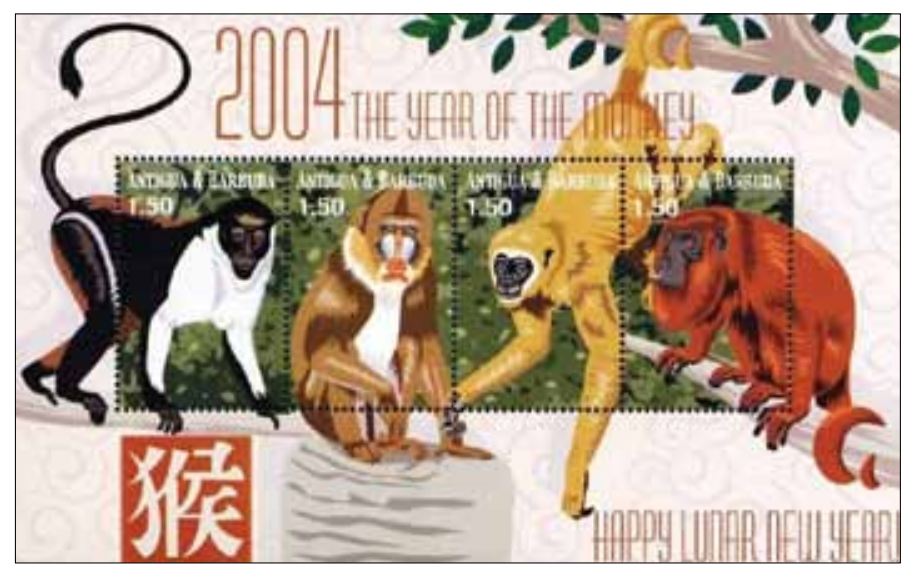

Figure 1. Chimpanzees had long been carriers of a virus

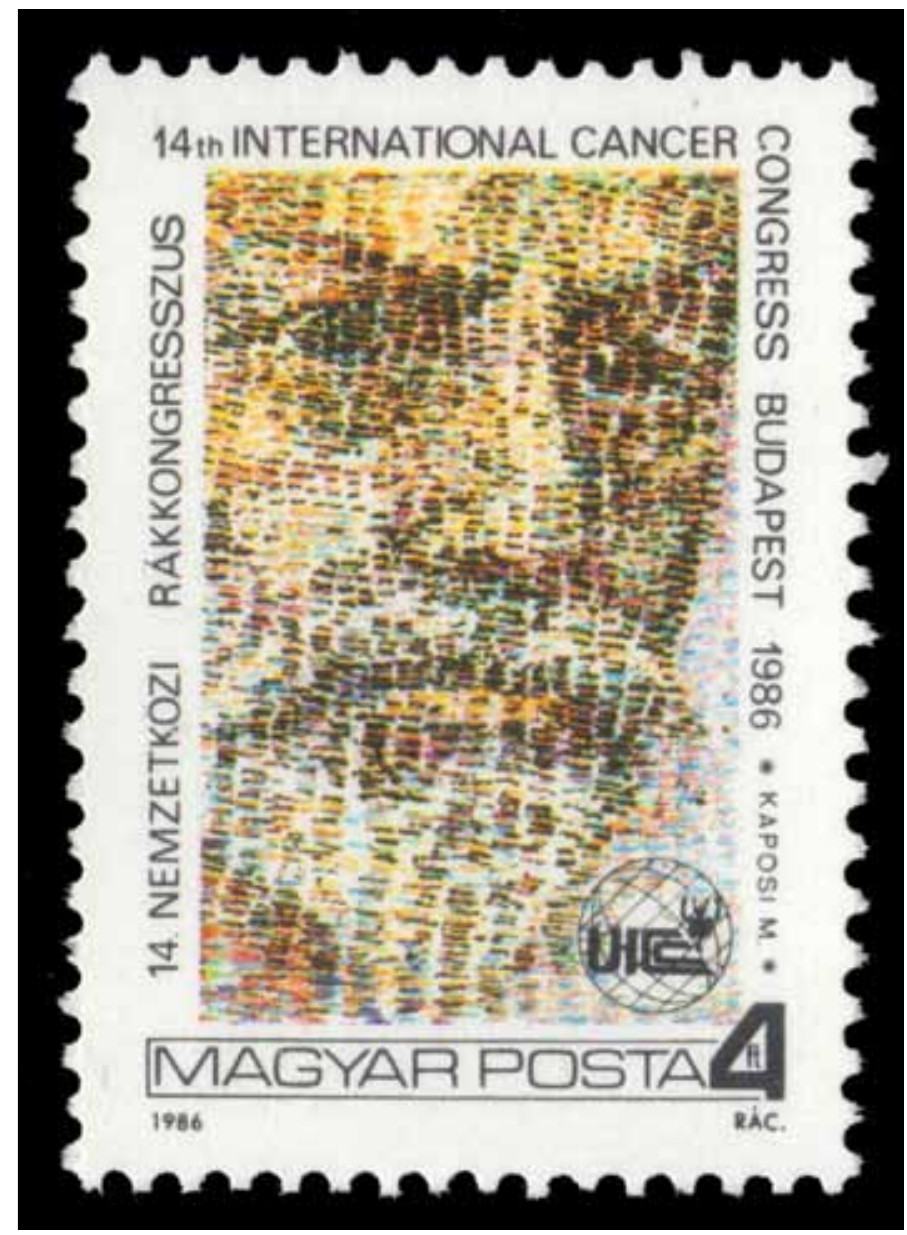

Figure 2. This stamp was issued to Kaposi stamp from Hungary

In 1981 doctors in New York and San Francisco began reporting cases of young, active homosexual men dying from Kaposi's Sarcoma, a rare type of skin cancer which usually occurs after a breakdown in the immune system. Other types of death resulting from immunodeficiency then began occurring with alarming frequency, and the medical profession realized that it was faced with a new and highly dangerous infectious disease, which it named AIDS. As panic spread,

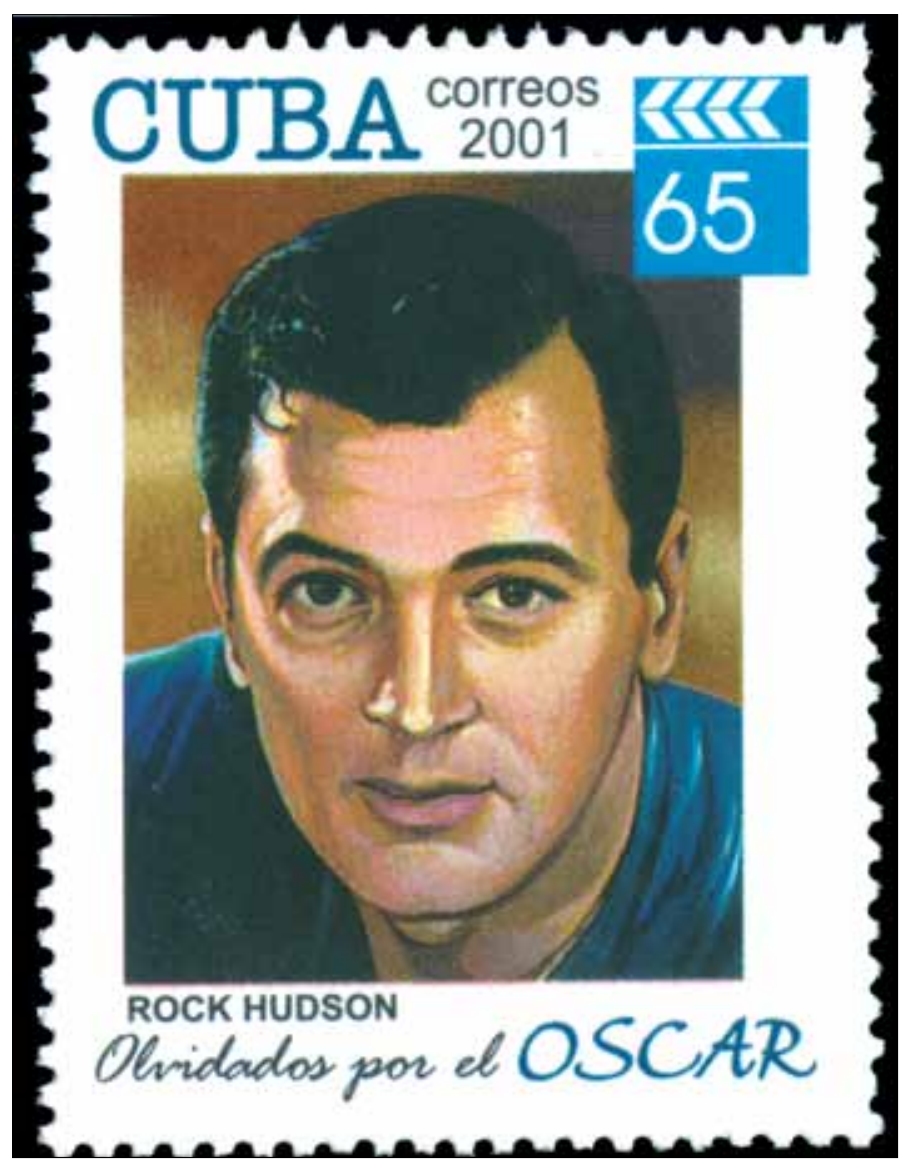

Figure 3. The famous American actor Rock Hudson, who died from AIDS in 1985 on a Cuban stamp

others began calling it "the gay plague", while fundamentalist preachers declared that it was the wrath of God descending on the inhabitants of the licentious San Francisco and other sinks of homosexual iniquity. Soon, however, reports of AIDS began coming in from countries worldwide, and it became clear that this was not a disease limited to homosexuals. In sub-Saharan Africa, the disease had spread along the main highways running east and west, transmitted by male lorry drivers to the female prostitutes along their routes. By 1984, 50 percent of Kenya's prostitutes were HIV positive. By the following year, 10.000 people in the United States alone were infected, and the majority would die within two years of being diagnosed. The disease spread through all levels of society, taking a particularly heavy toll on the artistic and intellectual community. In France, the philosopher Michel Foucault would be the first well-known American figure to declare publicly that he had AIDS shortly before he died in November 1985. Also, there was a big scandal when a very famous American actor Rock Hudson died from AIDS in October 1985 (1) (Figure 3).

\section{Transmission of the disease}

By now considerable research had been carried out into AIDS. It had been discovered that the disease was spread through the transmission of sexual fluids or blood. It could enter by way 
of cuts or abrasions, particularly those caused in the sensitive tissues of the sexual organs and the anus. Another prevalent way of passing on the disease was the shared use of syringes by drug abusers. Pregnant women could pass on HIV to their fetuses by way of their bloodstream, and even after birth HIV could be passed on through the mother's milk. It was also found to be passed on to people requiring blood transfusions, such as hemophiliacs-there was still no test which could detect the HIV virus in blood samples. However, despite all the hysteria, it was soon understood that the disease was not passed on by normal social contact, or even deep kissing; and "safe sex" (involving careful use of a condom) also prevented possible contamination (1) (Figure 4).

\section{Structure of the Virus}

HIV was found to be a retrovirus that affected the white blood cells known as Helper $\mathrm{T}$ cells, which were essential to the

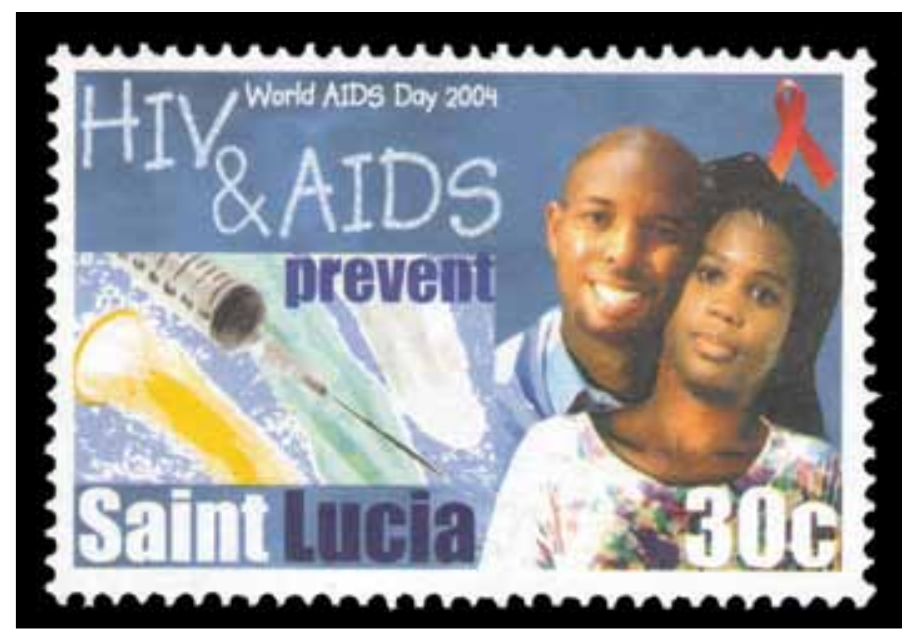

Figure 4. The propaganda of safe-sex is exhibited by a stamp from Saint Lucia body's immune system. Alarmingly, after the initial infection there was a long period during which the patient showed no symptoms of illness. This asymptomatic period could last for months, or even years, with the infected person unaware that he was HIV positive, while at the same time passing on the virus. During this stage Helper T cells were attacked by the HIV virus and gradually reduced from their normal density of 1000 per micro-liter to the critical point around 200 per microliter, when the patient suffered from immune deficiency (AIDS). As a result he/she would be exposed to illnesses from tumors to diseases of the nervous system, and at the same time also be liable to suffer from such distressing symptoms as personality changes, memory blanks and dementia. On top of this, viruses which had long lain dormant in the body were no longer suppressed and became active. This latter aspect contributed to the rise in tuberculosis around this period (1) (Figure 5, 6).

The quest for a vaccine to combat AIDS began early, but major difficulties soon became apparent. The HIV virus was found to be capable of mutating into new strains even more rapidly than the influenza virus. Normally, a vaccine would only be capable of combating a single strain. At the same time,, anyone who did come up with a successful vaccine would be assured of worldwide gratitude, to say nothing of the unimaginable fortune which the patent rights would bring.

Two front runners in the race to develop a vaccine soon emerged-the American Robert Gallo and his team at the National Institutes of Health in Maryland, and a French team at the Pasteur Institute under Luc Montagnier. One after another, these two researchers discovered the structure of the virus that causes AIDS what we now called HIV . In 2008, Francoise BarreSnoussi and Luc Montagnier shared the Nobel Medicine Prize for their discovery of the HIV virus (2) (Figure 7).
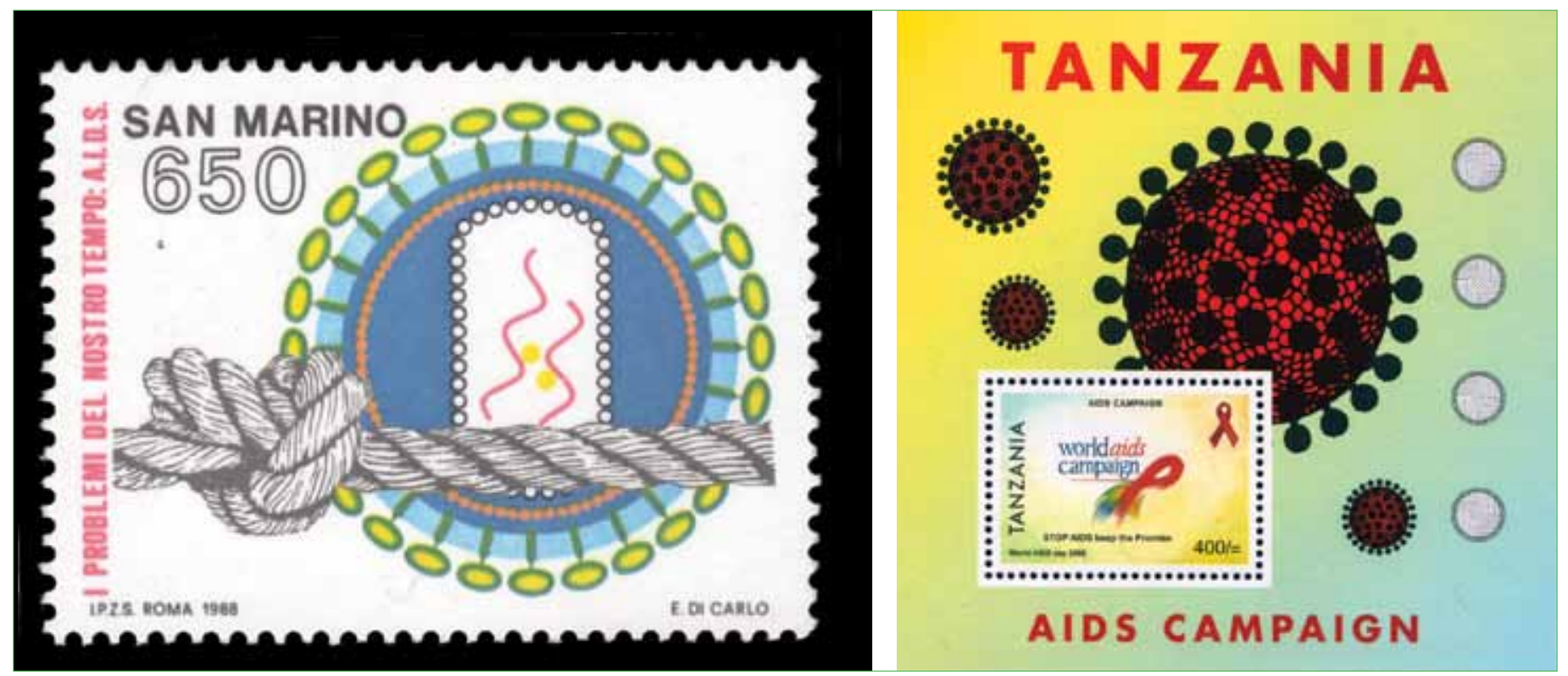

Figure 5, 6. HIV virus represented on San Marino and Tanzania stamps 


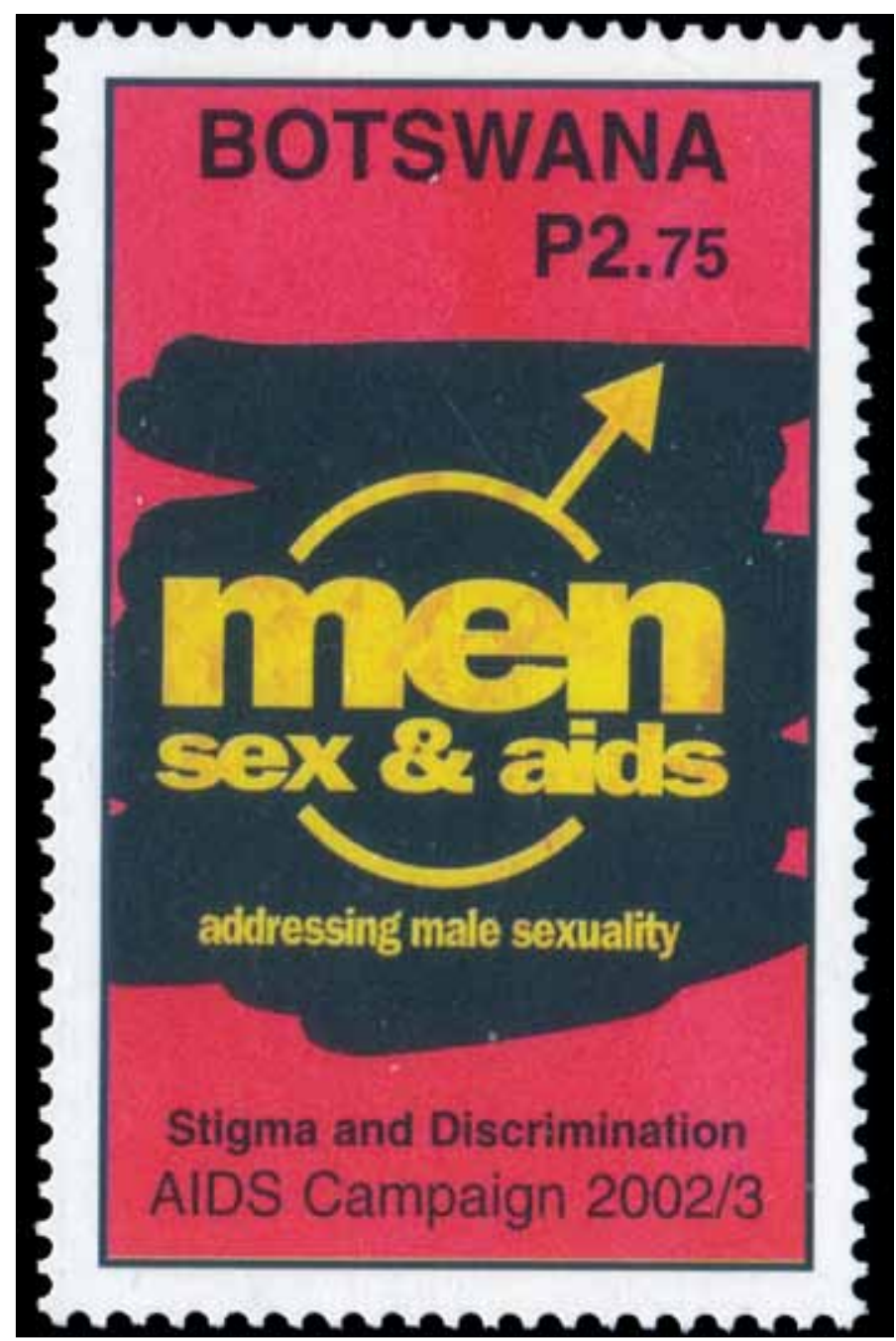

Figure 7. A stamp from Botswana emphasizing stigma and discrimination in AIDS

\section{Some Ethical Considerations}

Despite all the scientific researches developing new drugs and producing really effective pharmaceutical agents, the main ethical issues related to HIV/AIDS testing including confidentiality, informed consent, end of life, research design, conflict of interest, vulnerable populations, and vaccine research are still continuing (3).

According to the contemporary approach, all medical information is generally considered confidential and protected under the law. Because of the sensitivity of HIV-related information, many countries have adopted laws that provide additional protection to HIV-related medical records. For example, in many countries, HIV information may not be disclosed based on a general release of medical information-specific authorization for release of HIVrelated information must be obtained (4) (Figure 8).

Vulnerability is particularly important in the context of HIVrelated research. Those infected with HIV may be medically vulnerable because of their infection. In addition, homosexuals, injection drug users, minorities, and women, who, for various reasons, may be at higher risk of HIV infection, are more likely to be socially and economically vulnerable because of historical

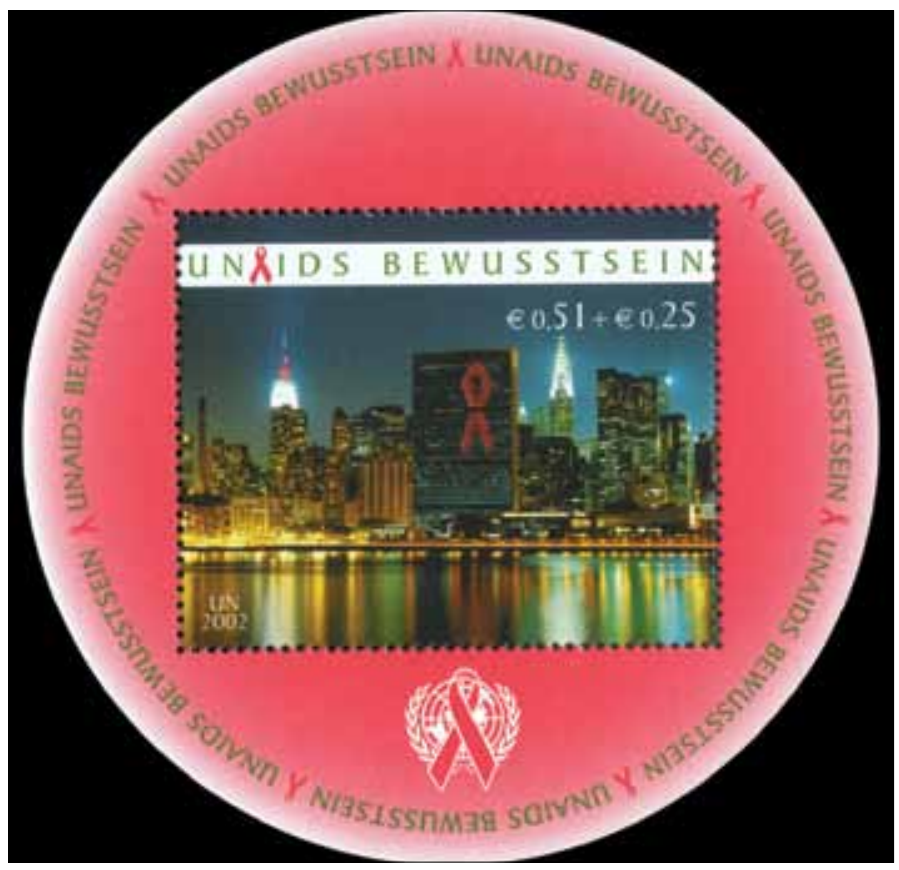

Figure 8. World AIDS day on the stamp from United Nations Organization

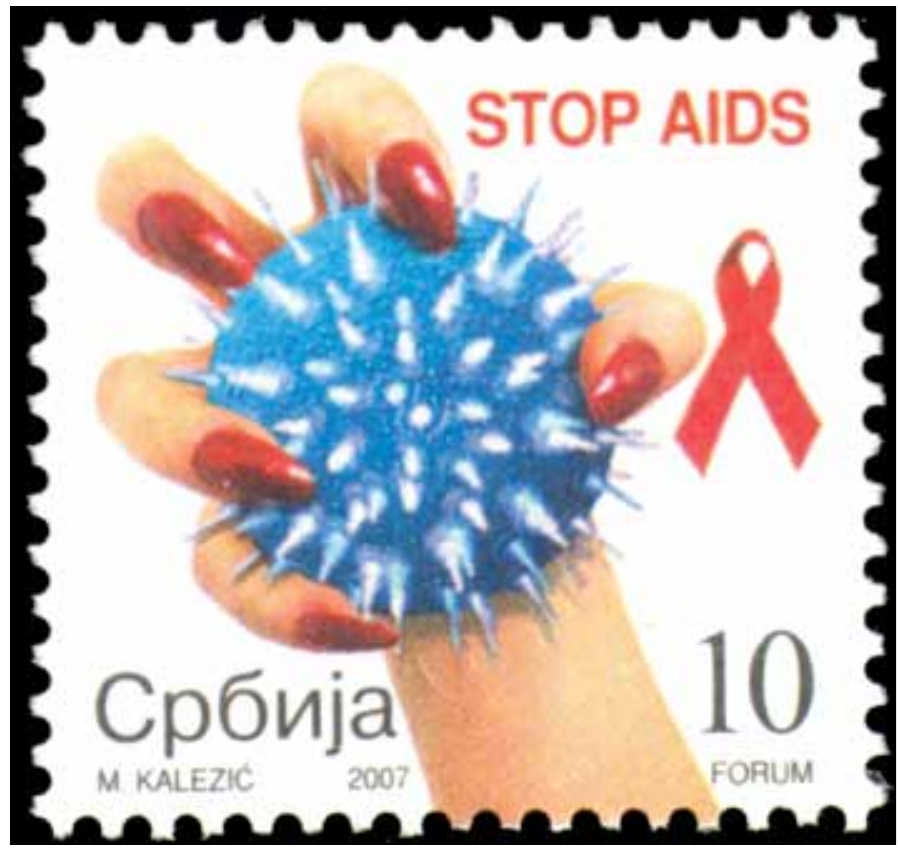

Figure 9. Stamp is showing the importance of fighting against AIDS

attitudes and discrimination. Accordingly, investigators conducting HIV-related research must pay particular attention to vulnerability and take steps to protect potentially vulnerable research participants (5) (Figure 9).

\section{Conclusion}

Most agree that the epidemic is gradually being brought under control in many advanced Western countries, whereas it is undeniably out of control in Africa and many Third World 
Table 1. Philatelic table of the history of AIDS through Philately

\begin{tabular}{|l|c|c|c|}
\hline Name & Year & Country & Scott Nr \\
\hline Year of monkeys & 2004 & Antigua \& Barbuda & $2752 \mathrm{e}$ \\
\hline $\begin{array}{l}\text { 14 } \\
\text { Congr. }\end{array}$ & 1986 & Hungary & 2997 \\
\hline Rock Hudson & 2001 & Cuba & 4192 \\
\hline HIV \& AIDS & 2004 & Saint Lucia & 1198 \\
\hline AIDS & 1988 & San Marino & 1163 \\
\hline AIDS & 2006 & Tanzania & 2483 \\
\hline AIDS & 2002 & Botswana & 759 \\
\hline AIDS & 2002 & United Nations, Vienna & 325 \\
\hline AIDS & 2007 & Serbia & 371 \\
\hline
\end{tabular}

countries. How long this bipartite state of affairs can continue is uncertain. However, one thing is certain: similar diseases will continue to appear at more or less lengthy intervals. In the blind process of natural selection, human beings are far from being alone in their struggle for survival on this planet. In order to survive, viruses too will evolve and discover their methods of adapting to circumstances. Yet, in discovering how to overcome AIDS, and finding a vaccine against such an elusive virus as HIV, humanity may well discover the means to win these battles in the future to. Above all, the total list of the philatelic material used in this article is shown in Table 1.

\section{Conflict of interest}

No conflict of interest was declared by the authors.

\section{References}

1. Paul Strathern, A Brief History of Medicine from Hippocrates to Gene Therapy, (New York: Carroll and Graf Publishing House, 2005), p.376-8.

2. Bryan CS. HIV/AIDS and Bioethics: Historical Perspective, Personal Retrospective. Health Care Analysis 2002; 10: 5-18. [CrossRef]

3. Holtgrave, Science, Values and The Public Health Agencies: AIDS Education and Prevention, New York 2003; 15: p. 203-5. [CrossRef]

4. Ferriman A. Doctors Demand Immediate Access to Antiretroviral Drugs in Africa. BMJ 2001;322:1012

5. Joint United Nations Programme on HIV/AIDS (UNAIDS). Ethical Considerations in HIV Preventive Vaccine Research, Geneva, 2000; p. 5-17. [CrossRef]

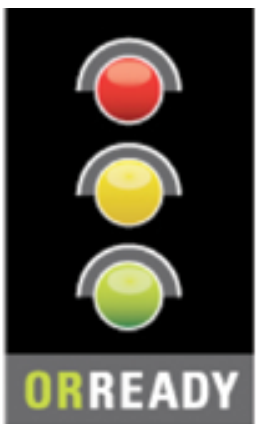

We are ORReady and support operating room safety to improve patient outcome.
ORReady is a worldwide, multi-Specialty initiative to encourage steps that are known to improve surgical outcomes and save lives.

If the suggested guidelines, which include Check Lists, Time Outs and Warm Ups are followed routinely, we estimate that Six Million patients around the world could have better outcomes.

Find out how your department and hospital can be ORReady and improve outcomes at http://www.sls.org/outcome 